\title{
TAPAЗАНОВ Игорь Геннадьевич
}

$(24.12 .1959-11.11 .2021)$

Дорогие читатели, редакция журнала «Уголь» понесла невосполнимую утрату - 11 ноября 2021 г. на 62 году жизни скончался горный инженер, Заслуженный работник ТЭК, генеральный директор ООО «Редакция журнала «Уголь», заместитель главного редактора журнала «Уголь» Таразанов Игорь Геннадьевичь. На протяжении более 38 лет он непосредственно занимался формированием каждого выпуска журнала и руководил редакцией.

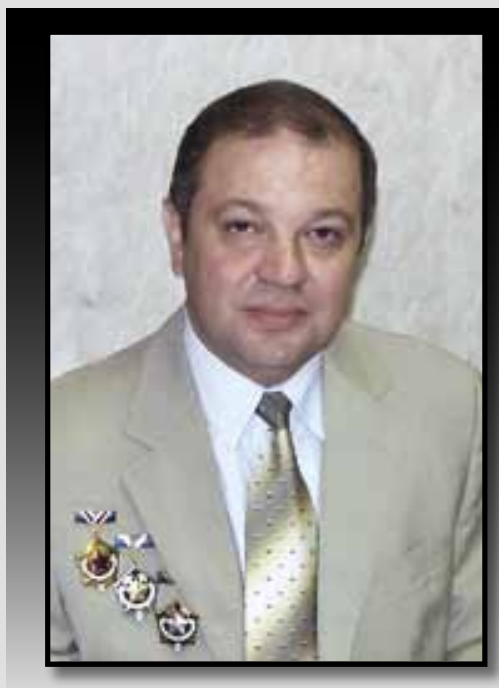

Игорь Геннадьевич родился в Кузбассе в шахтерском городе Киселевске в семье шахтеров. В 1972 г. вся семья переехала на Донбасс в шахтерский город Краснодон. В 1977 г., после окончания средней школы № 1 им. М. Горького в г. Краснодоне (школа, воспитавшая 28 молодогвардейцев), он поступил в Московский горный институт на специальность «Технология и комплексная механизация подземной разработки пластовых месторождений угля». В период учебы в институте, с 3-го курса и до окончания учебы, Игорь Геннадьевич был комсоргом студенческой группы ТПУ-1-77. Учебную и производственную практику проходил на Эльбрусе, на студенческой шахте в ПО «Ставрополь-уголь», а также на шахте им. XXVI съезда КПСС (быв. шахта «Таловская») ПО «Краснодонуголь». В 1982 г. с отличием окончил институт, получив специальность горного инженера. Награжден ректором В.В. Ржевским именными часами и знаком Минвуза и ЦК ВЛКСМ «Отличник учебы» и был распределен на работу в редакцию журнала «Уголь» издательства «Недра».

Игорь Геннадьевич начинал свою трудовую деятельность в издательстве «Недра» редактором, затем работал старшим редактором, научным редактором, старшим научным редактором. В 1988 г. приказом министра угольной промышленности СССР М.И. Щадова был назначен заместителем главного редактора журнала «Уголь». Он возглавил редакцию в возрасте 28 лет и на то время являлся самым молодым руководителем в издательстве «Недра», которое объединяло 15 редакций научно-технических журналов, 10 книжных редакций и редакцию плакатных изданий, вел активную общественную работу - в 1985-1989 гг. являлся секретарем комитета комсомола издательства «Недра».

С 1986 г. и до распада СССР был членом компартии. В августе 1991 г. во время путча ГКЧП был среди защитников Белого дома.
В 1990-е - начале 2000-х гг. Игорь Геннадьевич приложил немало усилий по сохранению научно-технического журнала: из издательства «Недра» редакция перешла в компанию «Росуголь», затем в издательство АГН, ЗАО «Росинформуголь», НК «Уголь-Фонд».

В 2005 г. редакция стала самостоятельной организацией - ООО «Редакция журнала «Уголь». И.Г. Таразанов возглавил это предприятие, стал генеральным директором. То, что издание «выжило» в трудные перестроечные годы, в годы реструктуризации угольной отрасли, и смогло из дотационного издания стать самостоятельным и развиваться уже в нынешних условиях, - в этом огромная заслуга бесценного руководителя и наставника коллектива редакции И.Г. Таразанова.

С 1992 по 2004 г. И.Г. Таразанов работал под непосредственным руководством первого заместителя главного редактора, бывшего министра угольной промышленности СССР Б.Ф. Братченко. Также большое влияние на становление и формирование Игоря Геннадьевича как личности оказали выдающиеся организаторы и руководители угольной промышленности, являвшиеся в разные годы главными редакторами журнала Уголь: Г.И. Нуждихин, А.А. Манжула, В.М. Ждамиров, В.Е. Зайденварг, А.Е. Евтушенко, Е.Я. Диколенко, В.М. Щадов, К.Ю. Алексеев, А.Б. Яновский.

Заслуги И.Г. Таразанова перед угольной отраслью по достоинству оценены. Он является Заслуженным работником ТЭК, полным кавалером знака «Шахтерская слава» и знака «Горняцкая слава», награжден почетными грамотами Минуглепрома СССР, Госкомиздата СССР, ЦК Профсоюза работников угольной промышленности, компании «Росуголь», Минтопэнерго России.

Жестокая и несправедливая судьба отнимает у нас самое дорогое - родных и близких нам людей...

Игорь Геннадьевич был светлым и добрым человеком, высоким профессионалом в своем деле, скромным, интеллигентным и добропорядочным. И вся его жизнь была наполнена только добрыми делами. Светлая память о нем навсегда сохранится в наших сердцах. 